KAWISTARA

VOLUME $3 \quad$ No. 2, 17 Agustus 2013

Halaman 117-226

\title{
MEMAHAMI INGATAN KULTURAL YAHUDI DALAM KONFLIK ISRAEL-PALESTINA
}

\author{
Leonard C. Epafras \\ Program Studi Inter-Religious Studies \\ Sekolah Pascasarjana Universitas Gadjah Mada \\ Email: leonard.epafras@mail.ugm.ac.id
}

\begin{abstract}
This article is an assessment to the role of the Jewish cultural memory in the Israeli-Palestinian conflict. Cultural memory in this regard is a social or collective memory that links to the fateful moment(s) in the past. These past experiences shape the ones identities, way of life, self-image and perception, and the attitude toward the others. Jewish cultural memory is supplied by religious narratives, diaspora experiences, the emergence of Zionism, Holocaust/Shoah, and the rebirth of Masada historical moment. Those memories have a strong influence toward Israeli government in dealing with the conflict with the Arabs, especially with Palestinians.
\end{abstract}

Keywords: Israeli-Palestinian Conflict, Cultural Memory, Religious Narrative, Jewish History.

\begin{abstract}
ABSTRAK
Makalah ini bertujuan melihat kontribusi dari ingatan kultural bangsa Yahudi terhadap dinamika konflik bangsa Israel dan Palestina dewasa ini. Ingatan kultural adalah ingatan sosial atau kolektif yang merujuk pada momen atau peristiwa di masa lalu yang sangat menentukan. Pengalaman masa lalu ini membentuk identitas, sikap hidup, cara pandang terhadap diri sendiri dan orang lain. Ingatan kolektif Yahudi disediakan oleh narasi keagamaan, pengalaman diaspora, lahirnya Zionisme, peristiwa Holocaust/ Shoah, dan penemuan kembali peristiwa Masada. Ingatan-ingatan kolektif ini juga mewarnai kebijakan pemerintahan Israel dalam menangani konflik dengan bangsa Arab, khususnya bangsa Palestina.
\end{abstract}

Kata Kunci: Konflik Israel-Palestina, Ingatan Kultural, Narasi Keagamaan, Sejarah Yahudi. 


\section{PENGANTAR}

Peristiwa kekerasan yang terjadi dua tahun lalu (2012) di antara militer Israel dan Hamas memakan banyak korban dengan kerusakan infrastruktur yang parah. Ada kesan kedua belah pihak "bersemangat" untuk saling menghancurkan. Hamas mengklaim telah mengirim hampir 1.500 roket ke Israel, bahkan berhasil menguji kemampuan jarak jauh rudalnya yang mampu menjangkau pinggiran Tel Aviv dan Yerusalem/Al-Quds. Skor terakhir dalam episode kali ini adalah 167 orang Palestina tewas dan 1.202 lainnya luka-luka.

Siapa yang menang dan siapa yang kalah? Jawabannya bergantung dari cara pandangnya. Hamas tampaknya yang keluar sebagai pemenang, terutama kemenangan diplomatik. Israel tidak banyak mendapatkan keuntungan kecuali berhasil memamerkan keunggulan teknologi Iron Dome dalam menangkis hujan roket dari Gaza. Yang paling babak belur, bukan saja penduduk Gaza, tetapi Mahmoud Abbas dan Palestinian Authority-nya yang tampak kurang menonjol dalam pertarungan ini, kalau tidak disebut pasif.

Rupanya pertempuran antara tentara Israel dan pejuang Hamas di Gaza barubaru ini bukanlah suatu peristiwa yang terisolir dan insidentil. Perspektif global, perbenturan ini melibatkan sekian banyak aktor-aktor dunia, seperti Amerika Serikat, Uni Eropa, Rusia, Liga Arab, Iran, Turki, dan lain-lainnya. Demikian juga ada faktor domestik lainnya, yaitu setiap kali terjadi insiden semacam ini, maka hal itu menyeret komunitas Yahudi dalam polarisasi politik, baik sebagai warga negara Israel, maupun sebagai warga negara-negara lainnya. Warna global ini sekarang memasuki babak baru dengan meluasnya peperangan ke wilayah dunia maya (cyberwar).

Pemicu dari episode kali ini adalah terbunuhnya wakil Brigade Izz al-Din AlQassam, Ahmed Jabari. Pembunuhan ini rupanya mengacaukan upaya-upaya damai yang ada. Gershon Baskin, aktivis dari Israeli/ Palestinian Center for Research and Information, mengemukakan kekecewaannya karena beberapa jam sebelum terbunuhnya tokoh Hamas ini oleh militer Israel, baru saja ia menerima draft gencatan senjata permanen dari Hamas. Sudah ada sedikit titik terang dari konflik panjang ini. Pemerintah Israel mengetahui soal ini, tapi tetap saja membunuh Jabari (Hasson 2012). Baskin adalah mediator antara pemerintah Israel dan Hamas yang telah bekerja berbulanbulan untuk membangun kepercayaan di antara keduanya, baik langsung maupun lewat perwakilan Mesir. Pembunuhan Jabari segera saja mematikan rintisan upaya perdamaian ini, terutama komunikasi dengan kelompok pragmatik dari Hamas; kelompok yang berhasil menjaga gencatan senjata selama ini.

Tentu ada banyak kemungkinan penjelasan mengapa pemerintah Israel tidak "menginginkan perdamaian." Pertanyaan serupa juga bisa diarahkan kepada kerasnya posisi Hamas terhadap Israel. Tulisan ini tidak bermaksud memberi jawab pada alasan dibalik sikap "anti-perdamaian" yang ditunjukkan pemerintah Israel maupun Hamas, tetapi ingin memperluas diskusi dengan memahami latar persoalan ini yang tercermin dalam sikap maupun kecenderungan tertentu. Harus diakui jika konflik Israel-Palestina telah menjadi moralitas global. Melebihi isu-isu politik, kemanusiaan, dan sosial lainnya, isu ini menjadi magnet yang sangat kuat yang melibatkan sekian banyak pihak di luar pihak yang bertikai. Seringkali dinamikanya kurang mencerminkan substansi, bahkan konflik ini sudah menjadi ruang simbolik untuk unjuk moralitas tertentu, yaitu untuk menunjukkan the good and the bad guy.

Tulisan ini bertujuan, pertama, memahami ingatan kolektif (collective memory) dan kultural (cultural memory) bangsa Yahudi yang melatari konflik tersebut. Salah satu kulminasi dari proses ini adalah ideologi nasionalis Yahudi disebut dengan Zionisme. Tentu saja hal ini sangat rumit dan tak mungkin menjadi satu-satunya penjelasan tentang Zionisme. Namun demikian, penulis 
menganggap penting untuk melihat elemen kultural dalam konflik ini.

Kedua, tulisan ini dimaksudkan untuk memberi penjelasan yang tidak apologetik yang selama ini sering ditampilkan di ruang publik Indonesia. Konflik ini sudah sangat lama dan memakan banyak korban, terutama dari bangsa Palestina. Bukan saja korban nyawa dan material, tetapi terbentuknya kultur kekerasan, politik yang saling meniadakan, langgengnya kebencian, dan rasa tidak saling percaya. Semua itu mengendap dalam ingatan pelaku maupun korban dalam bentuk ingatan. Ingatan yang diwarisi, mewarisi, dan membentuk identitas. Jadi kedua belah pihak sebenarnya mewarisi dan mewariskan trauma sejarah.

Ketiga, melalui tulisan ini ingin membuka ruang pemahaman tentang ingatan kolektif kedua belah pihak yang dapat menjadi pendamping dalam upaya penyelesaian politik. Ingatan kolektif jauh lebih langgeng dalam membingkai konflik ini. Di samping penjelasan ilmu politik yang memandang perang sebagai pilihan rasional dan terukur, tulisan ini mau mendeteksi politik budaya dan the politics of unconscious yang melatari konflik dan bergerak di balik layar.

Keempat, tulisan ini dimaksudkan mengisi relung yang tidak banyak diisi dalam wacana publik di Indonesia yaitu perspektif Yahudi. Penulis tidak berpretensi paham sepaham-pahamnya ingatan kultural dan kolektif kaum Yahudi, terutama karena penulis bukan berada dalam tradisi Yudaisme. Semua ini disajikan hanya sejauh kompetensi penulis yang terbatas dan tak lepas dari bias.

Dikarenakan tidak mungkin membahas kekayaan ingatan kultural tersebut, maka di sini disajikan sebagian kecil saja. Pertama, pembahasan ingatan kultural, dilanjutkan pembahasan soal konsep tanah dan umat Yahudi, yang dikaitkan dengan diaspora Yahudi. Selanjutnya tentang Zionisme sebagai narasi tandingan diaspora Yahudi, dan terakhir adalah pembahasan ingatan kolektif yang didominasi oleh narasi Zionisme melalui pemanfaatan simbol- simbol kultural dan agama dalam perang. Semuanya disajikan serba ringkas untuk mengundang diskusi lanjutan yang lebih mendalam.

Awalnya harus dipahami bahwa tradisi keagamaan Yahudi yang disebut Yudaisme beragam dan majemuk. Ada berbagai ekspresi dan tradisi dalam Yudaisme, mulai dari ritus keagamaan antara aliran Ashkenazim dan Sefardim, komunitas-komunitas seperti Ortodoks, Liberal, Konservatif, "UltraOrtodoks," Hasidim, dan Posmodernis, maupun berbagai komunitas seperti komunitas Ashkenazim, Sefardim, Karaim, Mizrahim, Beta Israel, dan lain-lain. Belum lagi kenyataan bahwa Yudaisme tak selalu berkonotasi keagamaan, tetapi penanda sosial dan kultural juga sebab tidak semua orang Yahudi beragama Yahudi, bisa saja ateis, agnostik, ataubahkanseorangMuslim,Kristen, Buddhis, maupun menganut aliran-aliran spiritualitas. Demikian juga Zionisme adalah ideologi nasionalisme Yahudi yang senantiasa bermetamorfosis sesuai dengan konteks zaman dan memiliki banyak cabangnya: ada Zionisme Ortodoks, Revisionis, New Historian Zionists, dan seterusnya. Akan tetapi, untuk memudahkan diskusi, kemajemukan antara Yudaisme dan Zionisme tidak terlalu kentara dalam tulisan ini.

Di luar jagad Zionisme pun ada banyak suara-suara kritis Yahudi terhadap Zionisme. Jadi Yahudi tak berarti Zionis dan Zionis tidak saja datang dari kalangan Yahudi. Banyak sekali kelompok Kristen Fundamentalis di Amerika Serikat dan di berbagai tempat lain yang pro-Zionis, ataukah karena bias Orientalisme, alasan-alasan teologis, maupun keduanya. Di kalangan Yahudi non-Zionis terdapat tokoh-tokoh dan kalangan mulai dari yang mengambil posisi sangat antiZionisme dan pro-Palestina, seperti Noam Chomsky, Norman Finkelstein, Ilan Pappe, komunitas Neturei Karta, komunitas Hasidim Satmar, hingga yang moderat seperti Judah Magnes, Martin Buber, David Hartman, Rebecca Alpert, dan lain-lain (band. BenEzer 1974; Carey and Shainin 2004; Shatz 2004; Landy 2011). 


\section{Ingatan Kultural}

Hubungannya dengan diskusi ini dibedakan dua jenis ingatan: ingatan komunikatif dan ingatan kultural. Ingatan komunikatif adalah ingatan yang terbentuk dari aktivitas keseharian yang tidak merujuk pada peristiwa dan momen tertentu yang dianggap khusus, tetapi lebih berkaitan pada komunikasi antaranggota masyarakat dalam ruang sosial. Pembentukannya adalah bagian dari proses pembelajaran terus menerus. Contohnya adalah aktivitas berangkat dan pulang kantor, menulis, membaca, bercakapcakap, belajar bahasa, menggosip, dan seterusnya (Assmann, 1995: 126).

Sementara itu diluar aktivitas keseharian manusia, ada banyak peristiwa konflik dan kekerasan yang terjadi di masa kini berakar dari ketegangan yang tak selesai atau tidak diselesaikan di masa lampau. Ketegangan antara "Timur" dan "Barat," ketegangan antar-agama, ketegangan antar kelompok sosial, maupun etnik, dan sebagainya, rupanya merupakan ingatan-ingatan yang dibangun, dan senantiasa diproduksi, dialih turunkan, dan disebarluaskan dari generasi ke generasi.

Hal tersebut di atas yang mengantarkan pada gagasan ingatan kultural. Pada ingatan kultural dan sosial lainnya, ingatan-ingatan ini merujuk pada satu titik peristiwa atau berbagai peristiwa di masa lalu yang dimaknai dan disemai melalui produk-produk budaya atau narasi keagamaan tertentu, misalnya dalam ritual, tradisi, teks suci, monumen peringatan, cerita, konotasi budaya, retorika, bahkan dalam tabu-tabu tertentu (Assmann, 1995: 128). Ingatan kultural dalam hal ini adalah sebuah "himpunan pengetahuan yang mengarahkan tindakan dan pengalaman manusia dalam konteks interaksi di dalam masyarakat sekaligus hal-hal yang diperoleh (maupun dihasilkan) dari generasi ke generasi melalui praktek-praktek sosial yang berulang" (Assmann, 1995: 126). Melalui pengulangan tersebut ingatan kultural menciptakan benang merah dan ikatan saling pengaruh memengaruhi "antara masa kini dan masa lalu dalam konteks sosio- kultural" (Erll, 2008: 2). Ingatan kultural tidak menekankan akurasi peristiwa historis yang dirujuk, tetapi lebih pada makna bagi pembentukan identitas, aspirasi sosial, budaya dan keagamaan, pandangan masa lalu, kini, dan ke depan.

Melalui bingkai di atas, ada keunikan dari produk ingatan kultural yang berkaitan dengan peristiwa traumatik tertentu dalam sejarah yang senantiasa dirujuk. Misalnya bangsa Amerika saat ini membangun ingatan kultural di sekitar peristiwa 9 September melalui monumen peringatan di situs kehancuran gedung World Trade Center di New York, pembuatan film-film oleh Hollywood, dan produk-produk kultural lainnya. Peristiwa tersebut juga memengaruhi keputusan penyerangan militer ke Afganistan, dan berbagai operasi militer serta politik lainnya terlepas bahwa keputusan-keputusan tersebut adalah produk kalkulasi politik yang sistematik. Akan tetapi, melalui peristiwa tersebut secara komunal dan kolektif bangsa Amerika menjadi bangsa yang memandang dirinya (self-image) dan orang lain secara khas. Demikian juga bangsa Indonesia masih terbebani dengan ingatan-ingatan kultural kekerasan masa lalu di era kolonial, peristiwa Madiun, peristiwa 1965, peristiwa Priok, peristiwa 1998, dan lain-lain. Maupun bangsa Arab Palestina yang mengenang peristiwa pengusiran besar-besaran dari tanah mereka pada tahun 1948 yang dikulminasikan dalam ingatan kultural al-Nakba ("malapetaka").

\section{PEMBAHASAN \\ Ingatan Kultural akan Tanah dan Diaspora}

Ingatan kultural dalam tradisi keagamaan Yahudi (Yudaisme) salah satunya berkisar pada gagasan zakhor (kata kerja simperatif, "ingatlah") (lih. Childs 1962: Yerushalmi, 1996). Dari segi etimologi dan semantik istilah ini bersepupu dengan istilah Arab dhikr atau zikir ("mengingat"). Relasi pasang surut bangsa Yahudi dan Tuhan disetir salah satunya oleh gagasan ini. Pada tiap perhentian di tikungan 
sejarah, zakhor menentukan arah selanjutnya. Gagasan ini mengeja wantah dalam bentuk ritual keagamaan yang kompleks. Yudaisme adalah salah satu agama di dunia yang punya banyak ritus. Semua itu mencerminkan akan peranan ingatan kolektif.

Yudaisme secara umum, rujukan penting yang memengaruhi pandangan Yahudi terhadap diri mereka dan dunia ini adalah monoteisme, tanah, bangsa Yahudi, dan Taurat (Jacobs 1984, 1, 157159). Narasi Yahudi tradisional, tanah sangat krusial. Relasi ilahi dan bangsa Yahudi diselenggarakan pada tanah yang dipandang sudah ditentukan oleh Tuhan menurut kitab suci Yahudi (Tanakh). Tanakh adalah singkatan dari T(orah), N(evi'im) dan K(etuvim), yaitu Taurat, Kitab Nabi-nabi, dan Tulisan-tulisan. Kecuali beberapa variasi kecil, isinya secara umum bersesuaian dengan Kitab Perjanjian Lama (PL) dalam tradisi Kristen. Tanah juga menjadi sarana pembenihan, penyemaian, dan pertumbuhan identitas Yahudi. Dari 613 mitsvot (tgl. mitzvah, yaitu anjuran dan perintah agama) yang disarikan dari Tanakh sebagian adalah perintah yang hanya bisa dilakukan di negeri Palestina/Israel (Rabinowitz, 2007, V: 7385). Sebagian darinya, bahkan hanya dapat diterapkan jika Bait Suci Yerusalem berdiri.

Bangsa Yahudi dipaksa keluar dari negerinya sebanyak dua kali (abad ke 5 SM dan tahun 70 dan 135 Sesudah Masehi.) oleh bangsa Babilonia dan Romawi. Akibat kegagalan aspirasi Mesianisme Yahudi. Yudaisme sejak itu berubah menjadi agama diaspora. Diaspora adalah konteks "pembuangan" atau "perantauan" bagi kaum Yahudi di mana mereka menyebar dan tersebar ke berbagai pelosok dunia. Puncak sejarah keagaamaan dari Yudaisme diaspora ini adalah lahirnya Yudaisme Rabinis sesudah abad pertama Masehi dan keberadaannya berlangsung sampai sekarang. Yudaisme Rabinis menekankan dan berkisar pada tradisi dan produk-produk Rabinis seperti Mishnah, Talmudim, Midrashim, dan hukum-hukum agama lainnya. Semua itu memperlengkapi kaum Yahudi untuk bertahan hidup dalam konteks diaspora. Perspektif agama, diaspora (galut atau golah) dipandang sebagai pembuangan dan hukuman Ilahi karena dosadosa bangsa Yahudi.

Pemahaman ini bertransformasi menjadi ingatan kolektif tentang keterbuangan mereka dari tanah leluhur yang terus menerus diingat dan dirujuk melalui ritual dan narasi kebangsaan. Contohnya adalah ungkapan l'shana ha-ba'a ve yerushalayim ("Tahun depan [merayakan] di Yerusalem") sebagai ungkapan kerinduan akan kembali ke tanah Palestina/Israel sepanjang masa, yang dilantunkan tiap kali merayakan hari raya Paskah. Yudaisme Rabinis ini belakangan menjadi narasi dominan keagamaan, sekalipun tradisi Yahudi lain yang tidak berpangkal pada ajaran para Rabi, alias non-Rabinis tetap lestari, misalnya kaum Samaria, yaitu keyahudian kelompok Samaria berada dalam perdebatan sepanjang masa, tetapi tidak dapat disangkal bahwa kelompok ini sangat dekat dengan tradisi Yudaisme. Yahudi Karaim, Beta-Israel (Falasha) dari Etiopia, dan beberapa aliran Yahudi moderen. Seringkali ketika kita merujuk suatu tradisi atau menyebut sesuatu itu "Yahudi" yang dirujuk sebenarnya adalah Yudaisme Rabinis atau turunan dari Yudaisme Rabinis. Demikian juga dalam tulisan ini, jika menyebut tradisi Yahudi umumnya berarti Yahudi dalam jagad tradisi Yudaisme Rabinis.

Masa diaspora ini di abad pertengahan di bawah kekuasaan Islam, ada dua pandangan yang berkembang tentang identitas bangsa Yahudi dan kaitannya dengan tanah. Pertama adalah pandangan universalisme Yahudi, yang diwakili oleh Moses Maimonides (11351204). Yaitu bahwa bangsa Yahudimempunyai aspek universalitas dan mempunyai tujuantujuan universal. Sekalipun Maimonides mengritik dua tradisi yang serumpun dengan Yudaisme, yaitu Kristen dan Islam, ia tetap mengakui banyak titik-titik persamaan di antara ketiganya. Ini dinyatakan misalnya dalam karyanya Hilkhot Avodah Zarah (1:3), yaitu isinya secara ringkas menyebutkan bahwa barangsiapa mengejar jalan kebenaran 
(derekh ha-emet), yaitu jalan monoteisme ia termasuk dalam rumah Abraham (beyt Avraham). Hilkhot Avodah Zarah adalah bagian dari karya monumental Maimonides, Mishneh Torah (Maimonides, 1987).

Kedua menekankan partikularisme bangsa Yahudi dan pentingnya kembali ke tanah Israel, yang diwakili oleh Yehudah ha-Levi (kl. 1075-1141). Ha-Levi sangat menekankan keunikan panggilan bangsa Yahudi dibanding dengan bangsa-bangsa lainnya. Sebagai sistem keagamaan, ia memandang Yudaisme bukan saja unik, tetapi juga unggul. Salah satu keunggulannya adalah adanya tanah Israel, yang pada masa hidup ha-Levi dikuasai oleh kaum Muslim. Oleh karena itu, kerinduan dengan sangat untuk kembali ke tanah dan menantikan pemulihannya kembali menjadi milik bangsa Yahudi. Pada karya utamanya, Kitab al-radd wa al-dalil fi nusr al-din al-dhalil ("Kitab sanggahan dan pembuktian agama yang dinistakan") atau dalam teks Ibraninya, Sefer ha-Kuzari (Halevi 1905), ada banyak hal baginya yang tidak dapat dicapai bangsa Yahudi dalam kondisi diaspora, misalnya spiritualitas. Spiritualitas Yahudi yang penuh hanya bisa tercapai jika bangsa Yahudi kembali ke tanah Israel (Halevi, 1905, IV: 17 (223)).

Sekalipun kedua pandangan ini saling tumpang tindih dan pada titik tertentu saling meneguhkan, tetapi dapat diduga pandangan kedua dari ha-Levi menjadi benih bagi nasionalisme dan gerakan antiDiasporisme Yahudi di kemudian hari. Kulminasinya adalah pada ideologi Zionisme yang muncul pada abad 19. Sedangkan pandangan pertama berkembang menjadi ideologi diasporisme dan bentuk ekstrimnya adalah sikap anti-Zionisme. Ini juga menjadi sikap Rabinis selama berabad-abad dalam menantikan penebusan bangsa Yahudi secara Ilahi, bukan manusiawi. Di masa kini sikap ini dianut secara radikal oleh kelompok Yahudi Neturei Karta dan Hasidim Satmar (Rabkin 2006). Mereka sangat anti-Zionisme dan pro-Palestina sebab memandang Zionisme sebagai produk manusia belaka, bukan penebusan Ilahi.
Secara sederhana dapat dikatakan aspirasi Yahudi lainnya berada dan berkembang di antara kedua kutub ini.

\section{Penolakan Diaspora dan Zionisme}

Gagasan Zionisme bersemi di abad 19 dan berpuncak dengan traktat yang ditulis wartawan Austria keturunan Yahudi sekuler di tahun 1896, Theodor Herzl tentang Negeri Yahudi (Der Judenstaat). Der Judenstaat merupakan Judul lengkapnya adalah Der Judenstaat: Versuch einer modernen lösung der Judenfrage ("Negeri Yahudi: sebuah solusi moderen terhadap persoalan Yahudi") (T. Herzl, 2004). Diterbitkan dalam bahasa Inggris tahun 1946, dan Ibrani tahun 1953 (1946; 1953) Secara komprehensif Zionisme adalah kombinasi dan dihidupi oleh berbagai aspirasi. Di antaranya adalah (1) bangkitnya nasionalisme Yahudi sejalan dengan nasionalisme di Eropa dan dunia Arab, (2) respon terhadap antisemitisme dan penganiayaan (pogrom) orang Yahudi di Rusia dan Eropa Timur di akhir abad 19 dan awal abad 20, (3) reaksi terhadap meningkatnya asimilasi bangsa Yahudi ke dalam masyarakat Eropa.

Akan tetapi, menelisik lebih ke dalam, Zionisme adalah penolakan/negasi terhadap kehidupan Diaspora (shelilat hagalut). Secara ringkas Zionisme menolak kehidupan diaspora Yahudi yang sudah berumur berabad-abad itu, yang diwarnai dengan penganiayaan, pengusiran, migrasi, dan asimilasi. Bagi Zionisme dampak dari diaspora membentuk Yahudi yang berwatak budak, impoten, tergantung pada belas kasihan orang lain, pengecut, licik, lemah, dan berjiwa dangkal. Istilah yang khas disebut orang Yahudi diaspora adalah kaum luftmensch, manusia di awang-awang, tanpa akar budaya, dan wilayah.

Oleh Karena itu, Zionisme mau membangun narasi baru untuk mengakhiri narasi (ingatan kolektif) diaspora dengan membangun apa yang disebut the New Hebrew (orang Ibrani yang baru) sebagai identitas Yahudi yang otentik. Identitas yehudi (Yahudi) yang asal muasalnya lahir sebagai 
identitas di masa penjajahan Babilonia, Yunani, dan Romawi dan disemai di diaspora, ditransformasikan menjadi identitas "Ibrani" (Ivri). Identitas "Yahudi" (yehudi), yang merujuk pada Yahudi diaspora, dipandang sudah mengalami degradasi karena terasimilasi dengan bangsa dan identitas lain. Sepanjang sejarah diaspora "Yahudi" telah menjadi "Yahudi-Spanyol," "Yahudi-Arab," "Yahudi-Amerika," dan seterusnya. Mereka juga memakai bahasa-bahasa setempat dan/atau membangun bahasa Yahudi yang merupakan percampuran dengan bahasabahasa lain seperti Yiddish (Yahudi Jerman), Yudeo-Arabis (Yahudi Arab), Ladino (Yahudi Spanyol), dan lain-lain.

Reaksi terhadap kondisi yang "tidak murni" di atas, Zionisme menghilangkan tanda hubung identitas tersebut dan menggantikannya menjadi identitas "murni" Ivri (Ibrani). Bahkan istilah "Ibrani" ini dirujuk hingga jauh ke masa Kitab Suci demi menciptakan kesinambungan identitas. Bahasa Ibranipun menjadi bahasa otentik kaum Ibrani baru ini menggantikan bahasa Ibrani perantauan dan bahasa-bahasa Yahudi lainnya. Pada kenyataannya struktur bahasa Ibrani moderen ini dipengaruhi kaidah bahasa Indo-Eropa (Waltke and O'Connor 1990, 30n28, 350n16).

The New Hebrew ini diwakili dengan istilah Sabra (Almog 2000). Sabra adalah sejenis kaktus liar di padang rumput. Sama seperti kaktus ini, maka Sabra adalah tumbuhan yang keras di luar, tetapi lembut di dalam. Citra ini digambarkan sebagai manusia Ibrani yang kuat, mandiri, enerjik, progresif, moderen, tak kenal takut, dan cinta sesama bangsa Yahudi.

Sikap negasi ini berkelindan dengan perkembangan nasionalisme di Eropa sehingga Zionisme mengambil model Eropa sebagai citra bagi negara Israel yang moderen. Namun dalam perkembangan berikutnya model yang diambil adalah sosialisme, sebagai konversi dari komunalisme Yahudi yang sudah hidup berabad-abad. Zionisme awal a la Herzl terasa borjuis bagi Zionis generasi muda. Para Zionis muda yang kebanyakan bermigrasi dari Eropa Timur ini menjadi tulang punggung Zionisme menjelang berdirinya negara Israel moderen di tahun 1948. Dari pengalaman di Eropa Timur, Zionisme mewarisi gagasan dan praktek-praktek sosialisme. Itu sebabnya pemukiman Yahudi yang pertama (kibutsim dan moshavot) berbentuk komunitas sosialis yang ekonominya bertumpu pada koperasi. Sebuah kontras jika dibanding dengan penduduk Arab setempat yang umumnya masih tradisional dan membangun pola sosial berbasis kekerabatan.

Sabra menjadi model dan ingatan kolektif baru bagi bangsa Yahudi selanjutnya dan narasi Zionisme menjadi narasi dominan. Mentalitas ini dihidupi juga melalui konflik dengan bangsa-bangsa Arab sekitarnya, sehingga Sabra adalah simbol bangsa Israel yang kuat yang harus bertahan dari serangan bangsa Arab.

Jadi dari dunia Eropa, Zionismemewarisi gagasan nasionalisme, moderenisme, dan apa yang Edward Said sebut sebagai Orientalisme. Orientalisme memandang dunia di luar kaum kulit putih lebih rendah dan primitif. Dominannya narasi yang disumbang oleh kaum Yahudi Eropa "kulit putih" (Ashkenazim) ini menentukan corak Yahudi Israel selanjutnya sekaligus "menindas" narasi-narasi Yahudi non-"kulit putih" lainnya seperti Yahudi Sefardim (yang berasal dari Spanyol, Afrika Utara, Italia, Turki, dan Balkan), Yahudi Mizrahim (dari negara-negara Arab dan Iran), Yahudi Hitam (Falasha dari Etiopia), Yahudi Yaman, dan Yahudi-yahudi periferi lainnya. Orang-orang Yahudi ini harus "dikulit putihkan" terlebih dahulu untuk dapat diterima dalam struktur masyarakat Israel (Shenhav, 2006). Meskipun ada proses ideologisasi semacam ini tetap saja mereka didiskriminasi dan menjadi warga kelas dua, sekalipun kondisinya masih lebih baik dari warga Arab Israel. Baru belakangan ini terjadi perubahan mendasar.

\section{Holocaust/Shoah}

Bencana holocaust (Shoah, "bencana") Yahudi Eropa di tangan Nazi Jerman yang 
memakan jiwa yang sangat besar menjadi ingatan kolektif yang berdampak dahsyat bagi Zionisme dan bangsa Yahudi umumnya. Dalam perspektif Zionisme, Holocaust adalah puncak dari kemalangan hidup dalam diaspora. Seperti telah disinggung di atas, kemalangan itu terjadi sebagai tanda bahwa bangsa Yahudi diaspora adalah bangsa yang lemah yang tidak punya kekuatan politik dan militer bagi dirinya sendiri. Berdirinya negara Israel dipandang sebagai pemulihan dari impotensi sosial dan politik tersebut. Holocaust menjadi myth of origin bagi Zionisme dan Zionisme adalah "mesias" bagi kondisi bangsa Yahudi yang terpuruk tersebut. Holocaust menjadi legitimasi yang kuat bagi berdirinya negara Israel. Narasi Zionisme pada dasarnya adalah narasi tandingan Holocaust dan ia telah menjadi konotasi budaya. Itu sebabnya setiap kunjungan resmi kenegaraan ke Israel pastilah si pengunjung akan di bawa untuk berziarah ke museum Holocaust di Yerusalem (Museum Yad Vashem).

Holocaust juga menjadi rujukan kultural setiap kali negara Israel berada dalam situasi yang genting, misalnya ketika menjelang Perang Enam Hari 1967, Perang Yom Kippur, dan baru-baru ini dalam menghadapi potensi nuklir Iran. Dalam situasi seperti itu, ditambah dengan wilayahnya yang sempit (hanya separuh propinsi Jawa Tengah) dan terbuka terhadap serangan dari luar, maka ingatan kolektif Holocaust menjadi daya hidup untuk mempertahankan diri matimatian dengan harga berapapun. Sehingga pemerintah Israel (dan pemerintah Amerika Serikat) menginvestasikan perlindungan keamanan yang sangat mahal bagi penduduknya, seperti melalui teknologi Iron Dome, rudal Patriot, bunker bawah tanah, dan lain-lain.

\section{"Never Again Shall Masada Fall"}

Pada masa perjuangan kaum Yahudi melawan penjajahan Romawi di awal milenium, ada sebuah episode dramatis yang hanya dicatat oleh sejarahwan Yahudi klasik, Yosefus (37 - 100 SesM). Peristiwa itu adalah pengepungan pejuang Yahudi oleh tentara Romawi di Masada terhadap para pejuang Yahudi yang disebut kaum Zelot (Ioudaikou polemou pros Romaious, Book 7:VIIIIX, dalam Josephus 1981, 598-603). Masada adalah benteng alam berupa dataran tinggi yang terisolasi dari rangkaian dataran tinggi lainnya. Di benteng alam inilah kaum Zelot yang berjumlah kurang dari seribu orang, mempertahankan diri dari kepungan sepuluh ribu tentara Romawi yang berkemah di kaki dataran tersebut. Pengepungan berjalan hampir satu tahun, dan ketika kaum Zelot tidak menemukan harapan untuk selamat, mereka memutuskan untuk melakukan bunuh diri massal, ketimbang menyerah kepada tentara Romawi dapat dilihat catatan kritis tentang mitos "bunuh diri massal di Masada" dalam artikel Harriet Sherwood di koran The Guardian, 22 September 2013 (Sherwood, 2013).

Peristiwa ini selanjutnya "lenyap" dari ingatan kolektif Yahudi. Baru muncul kembali ketika pensiunan Jendral Israel, Yigal Yaedin melakukan ekskavasi di lokasi Masada di tahun 1960-an (Yadin 1966). Dampak dari ekskavasi ini luar biasa. Masada "lahir kembali" dan menjadi simbol patriotisme Zionisme (Coser, 1992, 32; Zerubavel 1995: 60-77). Kondisi dataran tinggi yang terisolasi dari dataran lainnya menjadi penanda dari kondisi Israel yang terisolasi dari bangsa-bangsa yang tak ramah terhadapnya. Sekalipun dalam Yudaisme tradisional bunuh diri itu haram hukumnya, narasi perjuangan kaum Zelot melawan tentara Romawi yang berkali lipat lebih banyak jumlahnya mencengkram imajinasi Zionisme. Negara Israel harus berhadapan dengan jumlah penduduk Arab di sekitarnya yang berkali lipat dari populasi Israel dan bersikap bermusuhan. Itu sebabnya mudah bagi Zionisme untuk mengidentifikasi diri dengan perjuangan kaum Zelot di Masada.

Kandidat tentara Israel (IDF - Israel Defense Force) dalam tiap akhir pelatihan militernya di Masada disebutkan akan mengucapkan kaul "Never again shall Masada fall" (shnit metsada lo tiful), "takkan 
lagi Masada dibiarkan jatuh" (Semmerling, 2004, 42-43). Ini menunjukkan sebuah tekad bahwa tak kan lagi terulang kesalahan sejarah Masada yang lalu ketika benteng alam itu jatuh ke tangan Romawi. Itu berarti Israel sebagai "Masada" yang baru harus dibela dengan segenap hati dan dengan harga berapa pun. Masada menjadi ingatan kolektif dan kultural baru yang diciptakan oleh pemerintah Israel.

\section{Simbol Agama dalam Konflik}

Jika di awal berdirinya negara Israel, ideal-ideal sosialisme (baca: sekulerisme) menjadi panduan utama dalam perpolitikkan lokal maupun sikap terhadap pihak Arab, maka saatini kita menyaksikan meningkatnya fundamentalisme Yudaisme yang makin mewarnai keputusan dan pilihan-pilihan politis pemerintah Israel. Hal ini semakin kentara melalui suara Partai Likud, dan partai-partai kecil agamis garis keras dan anti-Arab seperti Shas, Yisrael Beiteynu, dan lainnya yang selalu menjadi swing voters di Parlemen Israel (Knesset).

Contoh yang paling dekat dari kecenderungan ini adalah nama operasi militer yang disiapkan untuk menyerbu Gaza. Nama operasi tersebut adalah operasi Tiang Awan (Pillar of Cloud atau Pillar of Defense; amud anan). Tiang awan merujuk pada kisah dalam Tanakh yang mengisahkan keluarnya bangsa Israel dari Mesir yang dipimpin oleh Nabi Musa. Salah satu bagian dari kisah itu secara khusus berbicara tentang Tiang Awan ini.

TUHAN berjalan di depan mereka, pada siang hari dalam tiang awan untuk menuntun mereka di jalan, dan pada waktu malam dalam tiang api untuk menerangi mereka, sehingga mereka dapat berjalan siang dan malam (Shmot [Kitab Keluaran] 13: 21). Kutipan Tanakh/Perjanjian Lama dari Jewish Publication Society Hebrew-English Tanakh (1999) dan Alkitab Bahasa Indonesia terbitan Lembaga Alkitab Indonesia (1974).

Pada kisah ini digambarkan bahwa Tiang Awan menandakan perlindungan dan tuntunan Tuhan kepada bangsa Israel sepanjang perjalanan mereka dari Mesir menuju tanah terjanji. Tiang Awan inilah yang menahan dan menghalau tentara Firaun ketika bangsa Israel menyeberangi Laut Teberau.

Sementara itu dalam tradisi Talmud (dalam traktat Baba Metsia 86b), Talmud merujuk pada Talmud Babilonia (Epstein 1961).Tiang Awan disebutkan sebagai hadiah bagi bangsa Israel karena kebaikan dan sifat pendamai dari (Nabi) Harun. Harun digambarkan sebagai seorang yang selalu mencari jalan tengah dan jalan damai dalam setiap konflik (mis. dalam traktat Pirqe Avot 1: 12). Terjemahan Ben-Zion Halper (1921). Jadi sebenarnya ada dua lapis pemaknaan dari istilah Tiang Awan ini yaitu yang paling gamblang adalah Tiang Awan sebagai tanda perlindungan Tuhan bagi Israel dari situasi berbahaya, termasuk dari musuhmusuhnya. Sedangkan lapis kedua adalah perlindungan ini sebagai anugerah atas sifat pendamai dari Harun.

Pemerintah Israel memanfaatkan ingatan kultural keagamaan ini dengan menamai operasi militer mereka untuk menyerang Gaza. Jadi ada manipulasi ingatan kultural ini dengan memaknai perlindungan Israel dari musuhnya (Hamas) justru dengan cara ofensif. Ambivalensi ini menggemakan pernyataan almarhum PM Israel, Yitshaq Rabin: "tangan kami selalu terbuka untuk perdamaian, tetapi jari kami siap sedia di pelatuk [senapan]" (Zeiger, 2013).

Akan tetapi, sebenarnya hal yang lebih penting adalah penamaan ini secara halus mampu menarik simpati audiens lain di luar Israel, yaitu kelompok Kristen Fundamentalis dan kaum Kristen pro-Zionis di Amerika Serikat. Nama-nama dari kitab suci semacam ini akan memperkuat identifikasi melalui operasi ingatan kultural kelompok Kristen ini. Oleh Dalia Gavriely-Nuri, seorang ahli politik Universitas Bar-Ilan, Israel, strategi semacam ini disebut sebagai strategy of annihilative naming ("Penamaan demi tujuan penghancuran"). Ia mendata bahwa ada 239 operasi militer dan persenjataan Israel yang menggunakan nama-nama yang diambil dari Kitab Suci. Militer Israel menggunakan tiga strategi penamaan yaitu naturalisasi, 
eufemisme, dan legitimasi (Gavriely-Nuri 2010, 826). Tampaknya operasi Gaza yang terakhir ini, yang tidak jadi dilaksanakan, dipakai demi eufemisme dan legitimasi bagi perlindungan Israel dari serangan roket Hamas. Implementasi terakhir dari politik penamaan ini adalah teknologi pencegat rudal Ketapel Daud (David's Sling; qela dawid) (JPost 2012) tentunya mengingatkan banyak pembaca, terutama dalam tradisi Kristen dan Yahudi, pada peristiwa Daud yang mengalahkan Goliat dengan ketapel dalam cerita Kitab Suci.

Fundamentalisme agama mewujud melalui kehadiran partai-partai agama garis keras dan anti-Arab seperti Shas (Shomrei Sfarad ha-Torah, "Kaum Sefardi pembela Taurat"). Menteri Dalam Negeri Israel dari partai ini, Eliyahu "Eli" Yishai menyatakan di tengah ketegangan perang ini bahwa "kita akan buat Gaza kembali ke Abad Pertengahan" (Haaretz 2012). Pernyataan ini bukanlah pernyataan biasa, tetapi mencerminkan gambaran dunia yang khas seperti disebut di atas, yaitu Orientalisme. Inilah gambaran dunia yang dipengaruhi oleh kolonialisme Eropa. Gambaran yang memandang orang kulit putih lebih baik dari kaum Oriental (Arab, Afrika, Asia, dan lainnya). Jadi "dikembalikan ke Abad Pertengahan" bukan soal sepele mengalahkan musuh habis-habisan, tapi juga mencerminkan pandangan bahwa Palestina tak mungkin maju dan menjadi moderen. Pernyataan itu pun adalah proyeksi dari hasrat untuk mensabotase semua kemajuan yang dicapai Hamas. Menariknya adalah karena Eli Yishai adalah Yahudi Mizrahim, yaitu Yahudi Timur yang berasal dari Tunisia, bukan Yahudi "kulit putih" Ashkenazim yang sebenarnya secara kultural mewarisi bias Orientalisme dari Eropa, tempat mereka berasal. Ini menunjukkan betapa dalamnya pengaruh bias ini dalam wacana politik Israel.

\section{SIMPULAN}

Berbeda dengan ingatan komunikatif yang berada dalam aktifitas keseharian manusia dan tidak punya rujukan pada peristiwa tertentu, ingatan kolektif terpaku pada momen-momen menentukan di masa lalu. Momen-momen tersebut sangat memengaruhi identitas, sikap dan pandangan hidup masa kini maupun masa depan.

Dari pemaparan singkat di atas kita bisa menyaksikan peranan yang tak sedikit dari ingatan kultural tersebut dalam konflik Israel dan Palestina. Kisah-kisah dalam narasi Tanakh, pengalaman diaspora, lahirnya Zionisme sebagai perlawanan terhadap diaspora, Holocaust, Masada, dan seterusnya menjadi titik rujukan dari ingatan kolektif Yahudi yang menentukan pemahaman diri akan keberlangsungan hidup mereka di tengah kerumunan bangsa Arab.

Tampak bagaimana politik pemerintah Israel melalui retorikanya membingkai dan bermain dengan ingatan kultural tradisi Yahudi demi mengekalkan ketakutan dan kondisi perang. Bergayut dengan beban sejarah ini, keamanan dan rasa aman menjadi harga yang sulit dikompromikan bagi pemerintah Israel dalam tawaran perundingan damai apapun. Seringkali beban sejarah ini kontra-produktif dengan upaya perdamaian. Ingatan kolektif Yahudi yang dibingkai oleh pemerintah Israel menjadi salah satu sumber peneguhan atas harga yang harus dibayar demi rasa aman. Korbannya melanda kaum Yahudi sendiri, tapi terlebih lagi masyarakat sipil Palestina. Sinambung dengan beban ini, jika kelahiran negara Israel tak lepas dari narasi Holocaust/Shoah, bangsa Palestina harus menanggung narasi al-Nakba, penganiayaan dan pengusiran dari tanah mereka.

Lebih daripada itu, konflik ini didominasi oleh bahasa-bahasa kekerasan dari kedua belah pihak yang mematikan yang mentalitasnya tidak terlepas dari ingatan kultural masing-masing pula. Shoah dan Nakba sama-sama bermakna "malapetaka" tetapi keduanya dipakai secara berbeda oleh kelompok yang berbeda dalam kontestasi ingatan kultural. Keduanya sering dipakai sebagai pembenaran untuk peniadaan pihak 
lain. Situasi ini harus senantiasa dikritisi demi menuju kesepahaman dan dialog di antara kedua bangsa yang berseteru untuk melampauinya dengan memahami ingatan kolektif dan kultural masing-masing secara tepat. Perpolitikan di antara keduanya seringkali memanfaatkan benar ingataningatan ini untuk meneguhkan praktekpraktek kekerasan. Jadi perlu sikap baru untuk menghindari penyalah gunaannya.

\section{DAFTAR PUSTAKA}

Almog, Oz. 2000. The Sabra: The Creation of the New Jew. Diterjemahkan oleh Haim Watzman. Berkeley, Los Angeles dan London: University of California Press.

Assmann, Jan. 1995. "Collective Memory and Cultural Identities." New German Critique (65): 125-133.

Ben-Ezer, Ehud. 1974. Unease in Zion. New York: Quadrangle/New York Times Book Co.

Carey, Roane, dan Jonathan Shainin. 2004. The Other Israel: Voices of Refusal and Dissent. New York: The New Press.

Childs, Brevard S. 1962. Memory and Tradition in Israel. London: SCM Press.

Coser, Lewis A. 1992. “Introduction: Maurice Halbwachs 1877-1945." dalam Maurice Halbwach, On Collective Memory, disunting oleh Lewis A. Coser, 1-34. Chicago dan London: The University of Chicago Press.

Epstein, Isidore, peny. 1961. The Babylonian Talmud. 18 jilid. London: Soncino Press.

Erll, Astrid. 2008. “Cultural Memory Studies: An Introduction." dalam Cultural Memory Studies: An International and Interdisciplinary Handbook, edited by Astrid Erll and Ansgar Nünning, 1-15. Berlin dan New York: Walter de Gruyter.

Gavriely-Nuri, Dalia. 2010. "Rainbow, Snow, and the Poplar's Song: The
'Annihilative Naming' of Israeli Military Practices." Armed Forces and Society 36 (5): 825-842.

Haaretz. 2012. "LIVE BLOG: Day 4 of IsraelGaza Conflict 2012." Haaretz, 17 Nopember. http://www.haaretz. com/news/diplomacy-defense/ live-blog-day-4-of-israel-gazaconflict-2012-1.478505. Diakses 19 Nopember 2012.

Halevi, Judah. 1905. Kitab Al Khazari. Diterjemahkan oleh Hartwig Hirschfeld. London dan New York: George Routledge \& Sons and E.P. Dutton.

Halper, Ben-Zion (Benno), trans. 1921. Pirqe Avot [Sayings of the Fathers]. New York: The American Jewish Book Co.

Hasson, Nir. 2012. "Israeli Peace Activist: Hamas Leader Jabari Killed amid Talks on Long-Term Truce." Haaretz, 15 Nopember. http:/ / www.haaretz. com/news/diplomacy-defense/ israeli-peace-activist-hamas-leaderjabari-killed-amid-talks-on-longterm-truce.premium-1.478085. Diakses 20 Nopember 2012.

Herzl, Theodor. 1946. The Jewish State. Diterjemahkan oleh Sylvie D'Avigdor. New York: American Zionist Emergency Council.

2004. Der Judenstaat: Versuch Einer Modernen Lösung Der Judenfrage. eBook Bibliothek.

Herzl, Theodor (Binyamin Ze'ev). 1953. Medinat ha-Yehudim. Jerusalem: Newman Ltd.

Jacobs, Louis. 1984. The Book of Jewish Belief. New York: Behrman House.

Josephus, Flavius. 1981. The Complete Works of Josephus. Diterjemahkan oleh William Whiston. Grand Rapids, Mich.: Kregel Publications.

JPost. 2012. "Israel Successfully Tests David's Sling's Interceptor." Jerusalem Post, 25 Nopembers. 
JPS Hebrew-English Tanakh. Second Edition. 1999. Philadelphia: The Jewish Publication Society.

Landy, David. 2011. Jewish Identity and Palestinian Rights: Diaspora Jewish Opposition to Israel. London dan New York: Zed Books.

Lembaga Alkitab Indonesia. 1974. Alkitab. Bogor: Lembaga Alkitab Indonesia.

Maimonides, Moses. 1987. Hilchot Avodah Zarah/Avodat Kochavim v'Chukkoteihem. Disunting dan diterjemahkan oleh Eliyahu Touger. New York and Jerusalem: Moznaim Publishing.

Rabinowitz, Abraham Hirsch. 2007. "The 613 Commandments." Disunting oleh Fred Skolnik dan Michael Berenbaum. Encyclopaedia Judaica. Second Edition. Detroit: Macmillan Reference USA \& Keter Publishing House.

Rabkin, Yakov M. 2006. A Threat from within: A Century of Jewish Opposition to Zionism. Diterjemahkan oleh Fred A. Reed. London dan New York; New York: Fernwood Pub. and Zed Books.

Semmerling, Tim Jon. 2004. Israeli and Palestinian Postcards: Presentation of National Self. Austin, TX.: University of Texas Press.

Shatz, Adam. 2004. Prophets Outcast: A Century of Dissident Jewish Writing about Zionism and Israel. New York: Nation Books.
Shenhav, Yehouda. 2006. The Arab Jews: A Postcolonial Reading of Nationalism, Religion, and Ethnicity. Stanford: Stanford University Press.

Sherwood, Harriet. 2013. “Israel's Masada Myth: Doubts Cast over Ancient Symbol of Heroism and Sacrifice." The Guardian, September 22, sec. World news. http://www. theguardian.com/world/2013/ sep/22/israel-masada-myth-doubts. Diakses 24 September 2013.

Waltke, Bruce K., dan Michael P. O'Connor. 1990. An Introduction to Biblical Hebrew Syntax. Winona Lake: Eisenbrauns.

Yadin, Yigael. 1966. Masada: Herod's Fortress and the Zealot's Last Stand. New York: Random House.

Yerushalmi, Yosef Hayim. 1996. Zakhor: Jewish History and Jewish Memory. Seattle dan London: University of Washington Press.

Zeiger, Asher. 2013. "Left, Right Split on Response to Soldiers' Killings." The Times of Israel, September 23, sec. Israel and the Region. http://www. timesofisrael.com/left-right-spliton-response-to-killings-of-soldiers/. Diakses 10 Januari 2014.

Zerubavel, Yael. 1995. Recovered Roots: Collective Memory and the Making of Israeli National Tradition. Chicago: University of Chicago Press. 